\title{
Short Communication: Trees species diversity and indicator species in Bedugul forest ecosystem, Bali, Indonesia
}

\author{
SUTOMO ${ }^{\vee}$ I DEWA PUTU DARMA, ARIEF PRIYADI, RAJIF IRYADI \\ Bali Botan Gardens, Indonesian Institute of Sciences. Candikuning, Baturiti, Tabanan 82191, Bali, Indonesia. Tel.: +62-368-2033170, 2033170, \\ Fax.:+62-368-2033171, ’email: tommo.murdoch@gmail.com, sutomo.uwa@gmail.com
}

Manuscript received: 7 September 2018. Revision accepted: 9 November 2018.

\begin{abstract}
Sutomo, Darma IDP, Priyadi A, Iryadi R. 2018. Trees species diversity and indicator species in Bedugul forest ecosystem, Bali, Indonesia. Biodiversitas 19: 2213-2218. Bedugul area is an endorheic basin landscape with 3 lakes namely, Beratan, Buyan, Tamblingan, which is surrounded by Bukit Mangu, Tapak and Lesung. Topography of the area shows sloping to steep slopes with altitude on the lake surface $\pm 1,100 \mathrm{~m}$ asl and the highest peak of Bukit Mangu $2002 \mathrm{~m}$ asl. Ecological studies have not been optimal so identification of comprehensive ecological potential is carried out. Measurement of tree vegetation diversity was carried out by Centered Quarter Method and important value ratio analysis and location elevation class. The results of the inventory of tree species diversity in the Bedugul Bali forest area recorded 35 species and 13 indicator tree species. From the number of indicator tree species in the Mangu hill forest area there are 5 types of Ficus sp, Platea latifolia, Polyosma integrifolia, Lindera sp. and Syzygium sp., Bukit Tapak forest area consists of 4 species, Casuarina junghuhniana, Acronychia trifoliate, Astronia spectabilis and Homalanthus giganteus, the forest area of Bukit Lesung consists of 4 types of Lophopetalum javanicum, Syzygium racemosum, Dysoxylum nutans and Dendrocnide peltata.
\end{abstract}

Keywords: Bali, Bedugul, forests, Indicator species, R software

Abbreviations: CT: Confined basin/Cekungan terkungkung; CB: Biosphere reserve/Cagar biosfer; MB: Lower Mangu/Mangu bawah; MT: Middle Mangu/Mangu tengah; MA: Upper Mangu/Mangu atas; TB: Lower Tapak/ Tapak bawah; LB: Lower Lesung/Lesung bawah; LT: Middle Lesung/Lesung tengah; LB: Lower Lesung/Lesung bawah

\section{INTRODUCTION}

Bedugul area is a highland area in the middle of Bali Island, where there are three lakes (Beratan, Buyan, Tamblingan), Ulun Danu Beratan Temple, and the ex-situ conservation area, Bali's "Eka Karya" Botanical Garden. The natural landscape of this area is an endorheic basin or a confined basin (CT), which is an area in the form of a concave container that has no outflow (Hehanusa 2005) surrounded by Bukit Mangu, Tapak and Lesung. The development of this area is required to be in harmony with the conservation function. In 2005, a symposium was held with the title "Analysis of Carrying Capacity and Capacity of Water Resources in the Beratan Lake, Buyan and Tamblingan Areas". In the symposium, the appropriate management of the area was proposed in the form of Biosphere Reserves (BR). According to Man And Biosphere-Indonesia, (2013), the Biosphere Reserve is a site designated by various countries through the collaboration of the MAB-UNESCO program to promote conservation of biodiversity and sustainable development, based on the efforts of local communities and reliable science. According to the Republic of Indonesia Law No. 5 of 1999, a biosphere reserve is an area consisting of native ecosystems, unique ecosystems, and / or ecosystems that have undergone degradation whose whole natural elements are protected and conserved for research and education. The concept is a combination of preservation of landscape diversity, ecosystems, biological and genetic alignment with economic development, and in harmony with local cultural wisdom (Darnaedi et al. 2005).

On a national scale, Indonesia currently has 11 biosphere reserves, including the Cibodas Biosphere Reserve (1977), Komodo BR (1977), Lore Lindu BR (1977), Tanjung Putting BR (1977), Siberut Island BR (1981), Gunung Leuser BR (1981), Giam Siak Kecil-Bukit Batu BR (2009), Wakatobi BR (2012), Bromo Tengger Semeru-Arjuno BR (2015), Taka Bonerate-Kepulauan Selayar BR (2015), and Belambangan BR (2016) (MFA 2016). In relation to biodiversity in Bedugul, at the symposium in KREK in 2005, it was recommended that some native plants in the area could be reintroduced to restore function as a buffer zone. Some types found naturally include Cemara Pandak (Dacrycarpus imbricatus) and Cemara Geseng (Casuarina junghuhniana) (Sumantera 2004; Iryadi et al. 2017). Some species are rare and endemic species found in Bedugul forest areas such as Pinanga arinasae (Witono et al. 2002) and Dicksonia blumei (Darma et al. 2015).

As one of the research activities in Bali's "Eka Karya" Botanical Gardens in 2010, we have made a permanent sampling plot of 1 ha (Sutomo 2015) at Pohen Hill, which 
serves to study floristic diversity and potential carbon stocks. The results of this study revealed that the Bedugul $\mathrm{CT}$ area is very rich in biodiversity, including some rare species of flora that must be protected. Thus the unique and rich biodiversity of Bedugul $\mathrm{CT}$ area is very likely to become the next biosphere reserve. The management of this area has not been optimally conducted; comprehensive vegetation ecology has not been explored. Therefore, it is necessary to identify comprehensive ecological potential, including the diversity and dynamics of vegetation in the Bedugul highland forest ecosystem.

\section{MATERIALS AND METHODS}

\section{Study area}

Biophysical assessment activities were carried out in the basin area of Bedugul, Bali, Indonesia (Figure 1). Geographically, the research area was located at coordinates $115^{\circ} 05^{\prime} 00$ "-E $115^{\circ} 11^{\prime} 30$ "BT and 08 $18^{\circ} 30$ "-S 08 17'30"LS and altitude between 1,200-2,020 m asl. Based on information from KSDA Bali (2014), the location of the study of biophysical aspects was included in the area of Batukahu I Nature Reserve (Bukit Tapak) and Cagar Alam Batukahu III (Bukit Lesung). The ecosystem type is highland tropical rain forest, with the characteristics of high rainfall; the areas are always wet and have high floral biodiversity. According to the Schimdt and Fergusson climate classification, the type of climate is A with a mean annual rainfall of 2,000-2,800 mm per year, averaging 156 rainy days per year, 4-10 wet months and 05 dry months. The air temperature ranges from $11.5-24^{\circ} \mathrm{C}$.

\section{Procedures}

Observation of the diversity of tree vegetation in the Bukit Mangu, Tapak and Lesung forest areas was conducted in April 2014 and was done by Centered Quarter Method (Cox 1967). Observation plots were made based on the altitude/strata of every $100 \mathrm{~m}$ above sea level (Figure 1). Parameters observed included number of species, individuals, observation distance of tree species to observation points and tree trunk diameter measurements.

\section{Data analysis}

The approach to determining indicator species was by using important value index (IVI) approach of tree (Mitchell 2015) and also based on the distribution of the elevation location class. The acquisition of this important value was done by summing of three factors namely: relative density, relative cover and relative frequency from the results of field measurements. We then calculated the importance value ratio as well.

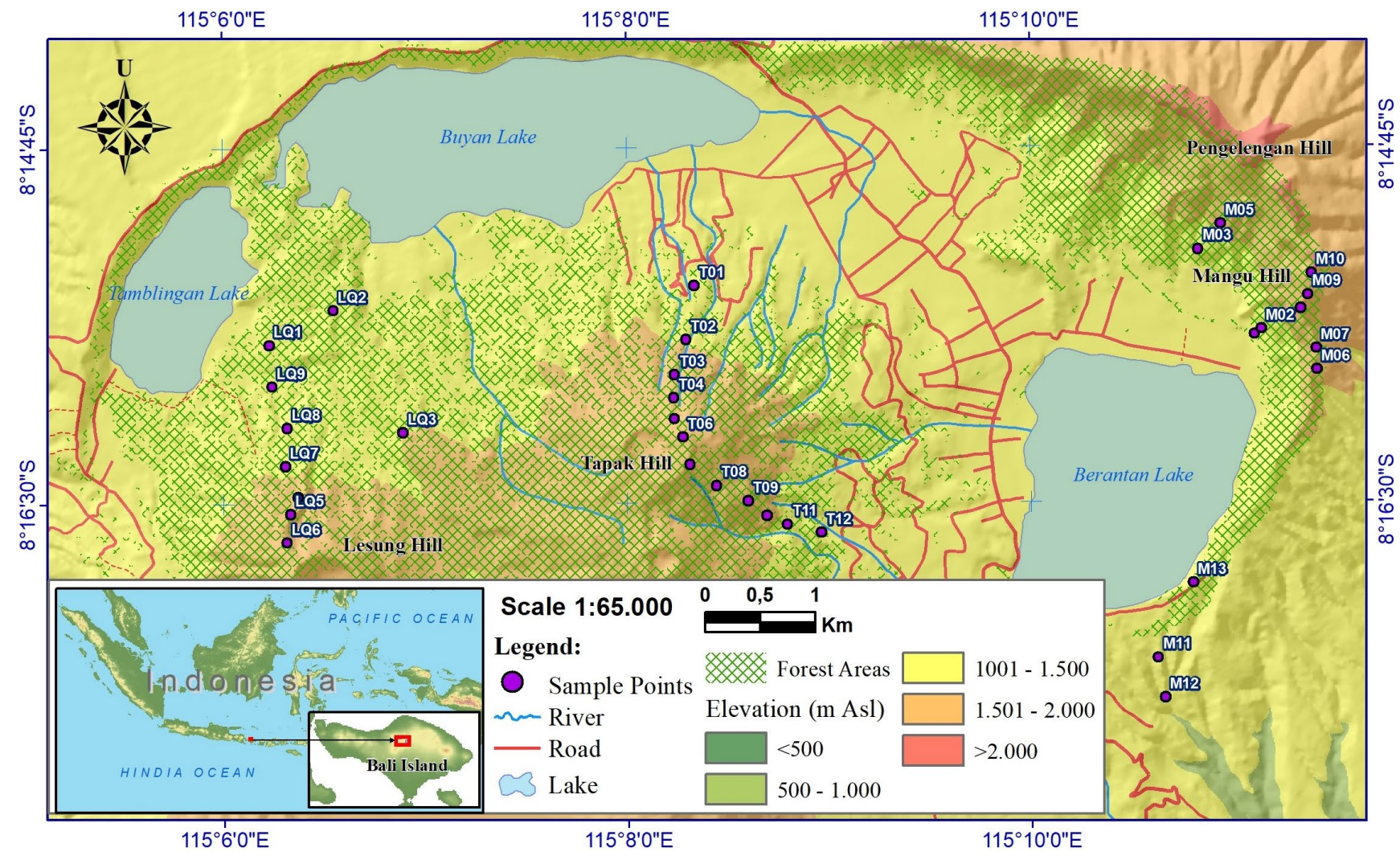

Figure 1. Location of observation points point-centered quarter method on the Hill of Mangu, Tapak and Lesung, Bali, Indonesia (BIG 2000) 
$\mathrm{Np}_{\mathrm{x}}=\mathrm{Kr}_{\mathrm{x}}+\mathrm{Tr}_{\mathrm{x}}+\mathrm{Fr}_{\mathrm{x}}$

$\mathrm{RNpx}=\frac{\mathrm{Npx}}{\sum \mathrm{Np}}$

Formula following Kent (2011).

Where :

$\mathrm{RNp}_{\mathrm{x}} \quad$ : Importance value ratio of species $\mathrm{x}$

$\mathrm{Np}_{\mathrm{x}} \quad$ : Importance value of species $\mathrm{x}$

$\mathrm{Kr}_{\mathrm{x}} \quad$ : Relative density of species $\mathrm{x}$

$\operatorname{Tr}_{\mathrm{x}} \quad$ : Relative coverage of species $\mathrm{x}$

$\mathrm{Fr}_{\mathrm{x}} \quad$ : Relative frequency of species $\mathrm{x}$

Cluster division used geometry interval classification using three classes based on the observation point elevation data points (Crisana 2014). There are three zones namely the bottom zone (B): 1,116-1420 $\mathrm{m}$ above sea level, middle zone (T): 1421-1,697 $\mathrm{m}$ above sea level, upper zone (A): 1,698-2,002 $\mathrm{m}$ above sea level. indicspecies package (De Caceres and Legendre 2009) in the $R$ program (R Core Team 2013) was used in this analysis. This computer program was created by The $\mathrm{R}$ Foundation for statistical computing based in Vienna, Austria. This program is used to work on various types of statistical analysis, one of which is the determination of indicator species.

\section{RESULTS AND DISCUSSION}

\section{Tree species diversity}

The diversity of tree species in the Bukit Mangu (Mangu Hill) consists of 27 species. The highest important value ratio of trees in this region was Ficus sp, and overall there were five species with the highest important value ratios scattered in the Mangu Hill Forest besides Ficus sp. There were also Platea latifolia, Polyosma integrifolia, Lindera sp. and Syzygium sp. (Table 1). The presence of Platea latifolia in this area was prominent with quite a lot of observational data but in the case of relative cover the species is far less compared to Ficus sp. because of the relative cover of the Ficus sp. tree. The average size of the Ficus sp. tree is greater than the others. Tree species diversity in Bukit Tapak recorded 23 species. Based on the value ratio, the highest five species positions were occupied by Dacrycarpus imbricatus (8.88), followed by Casuarina junghuhniana, Acronychia trifoliata, Astronia spectabilis and Homalanthus giganteus respectively (Table 2).

Bukit Lesung tree species diversity recorded 14 species. Based on the ratio of the importance of the trees, the highest five species' positions were occupied by Lophopetalum javanicum (14.76), followed by Syzygium racemosum, Dacrycarpus imbricatus, Dysoxylum nutans and Dendrocnide peltata (Table 3). When compared to other regions, the ratio of the importance of species in this region is high. Meanwhile, the composition of its diversity is almost similar to the conditions in the Bukit Tapak area.

Table 1. Tree species diversity in Mangu Hill Forest, Bedugul, Bali, Indonesia

\begin{tabular}{|c|c|c|c|c|c|c|}
\hline Species & Family & $\mathrm{Kr}(\%)$ & $\operatorname{Tr}(\%)$ & Fr $(\%)$ & Np (\%) & $\mathbf{R N p}$ \\
\hline Acronychia trifoliata & Rutaceae & 3.85 & 1.17 & 4.65 & 9.67 & 3.22 \\
\hline Adinandra javanica & Teaceae & 1.92 & 3.51 & 2.33 & 7.76 & 2.59 \\
\hline Bischofia javanica & Euphorbiaceae & 1.92 & 2.34 & 2.33 & 6.59 & 2.2 \\
\hline Cyathea latebrosa & Cyatheaceae & 5.77 & 1.55 & 6.98 & 14.30 & 4.77 \\
\hline Dendrocnide stimulans & Urticaceae & 1.92 & 1.59 & 2.33 & 5.84 & 1.95 \\
\hline Engelhardtia spicata & Juglandaceae & 1.92 & 1.59 & 2.33 & 5.84 & 1.95 \\
\hline Erythrina hypaphorus & Fabaceae & 1.92 & 2.7 & 2.33 & 6.95 & 2.32 \\
\hline Ficus benjamina & Moraceae & 1.92 & 11.06 & 2.33 & 15.31 & 5.1 \\
\hline Ficus fistulosa & Moraceae & 1.92 & 1.59 & 2.33 & 5.84 & 1.95 \\
\hline Ficus padana & Moraceae & 3.85 & 3.42 & 4.65 & 11.92 & 3.97 \\
\hline Ficus sp. & Moraceae & 1.92 & 32.86 & 2.33 & 37.11 & 12.37 \\
\hline Glochidion sp. 1 & Euphorbiaceae & 3.85 & 1.11 & 2.33 & 7.29 & 2.43 \\
\hline Hypobatrum sp. & Rubiaceae & 1.92 & 0.99 & 2.33 & 5.24 & 1.75 \\
\hline Ilex $\mathrm{sp}$ & Aquifoliaceae & 1.92 & 1.79 & 2.33 & 6.04 & 2.01 \\
\hline Lindera $\mathrm{sp}$. & Lauraceae & 5.77 & 4.14 & 6.98 & 16.89 & 5.63 \\
\hline Macaranga tanarius & Euphorbiaceae & 1.92 & 0.81 & 2.33 & 5.06 & 1.69 \\
\hline Pinanga arinasae & Arecaceae & 3.85 & 0.84 & 4.65 & 9.34 & 3.11 \\
\hline Platea latifolia & Icaccinaceae & 13.46 & 6.81 & 9.3 & 29.57 & 9.85 \\
\hline Platea sp. & Icaccinaceae & 1.92 & 0.17 & 2.33 & 4.42 & 1.47 \\
\hline Polyosma integrifolia & Saxipragaceae & 7.69 & 2.78 & 6.98 & 17.45 & 5.82 \\
\hline Polyosma sp. & Saxipragaceae & 1.92 & 1.23 & 2.33 & 5.48 & 1.83 \\
\hline Syzygium sp. & Myrtaceae & 7.69 & 3.62 & 4.65 & 15.96 & 5.32 \\
\hline Tabernaemontana macrocarpa & Apocinaceae & 1.92 & 1.06 & 2.33 & 5.31 & 1.77 \\
\hline Weinmannia sp. & Cunnaniaceae & 3.85 & 2.83 & 2.33 & 9.01 & 3.00 \\
\hline
\end{tabular}

Note: Kr: Relative density, Tr: Relative coverage, Fr: Relative frequency, Np: Importance value, RNp: Importance value ratio 
Table 2. Tree species diversity in Tapak Hill Forest, Bedugul, Bali, Indonesia

\begin{tabular}{|c|c|c|c|c|c|c|}
\hline Species name & Family & $\mathrm{Kr} \quad(\%)$ & $\operatorname{Tr}(\%)$ & $\operatorname{Fr}(\%)$ & Np (\%) & RNp \\
\hline Acronychia trifoliata & Rutaceae & 10.42 & 5.09 & 7.5 & 23.01 & 7.67 \\
\hline Adinandra javanica & Theaceae & 4.17 & 2.74 & 5 & 11.91 & 3.97 \\
\hline Albizia sp. & Legumioceae & 4.17 & 4.34 & 2.5 & 11.01 & 3.67 \\
\hline Astronia spectabilis & Melastomaceae & 8.33 & 4.96 & 7.5 & 20.79 & 6.93 \\
\hline Camelia sp. & Theaceae & 2.08 & 1.1 & 2.5 & 5.68 & 1.89 \\
\hline Casuarina junghuhniana & Casuarinaceae & 2.08 & 19.33 & 2.5 & 23.91 & 7.97 \\
\hline Cyathea latebrosa & Cyatheaceae. & 2.08 & 2.12 & 2.5 & 6.7 & 2.23 \\
\hline Dacrycarpus imbricatus & Podocarpaceae & 6.25 & 12.88 & 7.5 & 26.63 & 8.88 \\
\hline Dendrocnide stimulans & Urticaceae & 2.08 & 0.13 & 2.5 & 4.71 & 1.57 \\
\hline Ehretia javanica & Boraginaceae & 6.25 & 2.82 & 7.5 & 16.57 & 5.52 \\
\hline Elaeocarpus sphaericus & Elaeocarpaceae & 2.08 & 4.39 & 2.5 & 8.97 & 2.99 \\
\hline Engelhardtia spicata & Juglandaceae & 2.08 & 0.91 & 2.5 & 5.49 & 1.83 \\
\hline Erythrina hypaphorus & Leguminosae & 4.17 & 1.38 & 2.5 & 8.05 & 2.68 \\
\hline Ficus sp. & Moracaceae & 2.08 & 7.9 & 2.5 & 12.48 & 4.16 \\
\hline Glochidion sp. & Euphorbeacea & 2.08 & 0.39 & 2.5 & 4.97 & 1.66 \\
\hline Homalanthus giganteus & Euphorbeaceae & 8.33 & 2.04 & 10 & 20.37 & 6.79 \\
\hline Macaranga sp. & Euphorbeacea & 4.17 & 3.57 & 2.5 & 10.24 & 3.41 \\
\hline Polyosma integrifolia & Escalloniaceae & 6.25 & 1.51 & 7.5 & 15.26 & 5.09 \\
\hline Saurauia sp. & Actinidiaceae & 4.17 & 3.8 & 5 & 12.97 & 4.32 \\
\hline Syzygium sp. & Myrtaceae & 6.25 & 6.86 & 2.5 & 15.61 & 5.2 \\
\hline Syzygium sp. & Myrtaceae & 4.17 & 0.36 & 5 & 9.53 & 3.18 \\
\hline Syzygium sp. & Myrtaceae & 2.08 & 0.36 & 2.5 & 4.94 & 1.65 \\
\hline Trema orientalis & Cannabaceae & 4.17 & 11.01 & 5 & 20.18 & 6.73 \\
\hline
\end{tabular}

Table 3. Tree species diversity in Lesung Hill Forest, Bedugul, Bali, Indonesia

\begin{tabular}{|c|c|c|c|c|c|c|}
\hline Species name & Family & Kr (\%) & $\operatorname{Tr}(\%)$ & $\operatorname{Fr}(\%)$ & Np (\%) & RNp \\
\hline Acronychia trifoliata & Rutaceae & 6.25 & 3.75 & 8.33 & 18.33 & 6.11 \\
\hline Casuarina junghuhniana & Casuarinaceae & 2.08 & 11.59 & 2.78 & 16.45 & 5.48 \\
\hline Dacrycarpus imbricatus & Podoarpaceae & 8.33 & 19.94 & 8.33 & 36.60 & 12.2 \\
\hline Dendrocnide peltata & Urticaceae & 8.33 & 14.26 & 5.56 & 28.15 & 9.38 \\
\hline Dysoxylum nutans & Meliaceae & 10.42 & 7.73 & 11.11 & 29.26 & 9.75 \\
\hline Engelhardtia spicata & Juglandaceae & 4.17 & 13.64 & 5.56 & 23.37 & 7.79 \\
\hline Ficus benjamina & Moracaceae & 2.08 & 5.31 & 2.78 & 10.17 & 3.39 \\
\hline Ficus sp. & Moracaceae & 2.08 & 0.22 & 2.78 & 5.08 & 1.69 \\
\hline Homalanthus giganteus & Euphorbeaceae & 10.42 & 2.17 & 5.56 & 18.15 & 6.05 \\
\hline Lindera $\mathrm{sp}$. & Lauraceae & 2.08 & 0.1 & 2.78 & 4.96 & 1.65 \\
\hline Lophopetalum javanicum & Celastraceae & 14.58 & 15.82 & 13.89 & 44.29 & 14.76 \\
\hline Myrsine sp. & Primulaceae & 6.25 & 0.93 & 8.33 & 15.51 & 5.17 \\
\hline Polyosma integrifolia & Escalloniaceae & 2.08 & 1.58 & 2.78 & 6.44 & 2.15 \\
\hline Syzygium racemosum & Myrtaceae & 20.83 & 2.94 & 19.44 & 43.21 & 14.4 \\
\hline
\end{tabular}

In this study, tree species diversity was lowest in Lesung Forest compared to Mangu and Tapak. These results might have been caused by differences in the habitat condition of the forest itself. Lesung Forest which is located on Lesung Hill, is more populated but gaps have been created inside the forest. Land use change as a result of anthropogenic disturbance has caused the low diversity of tree species.

\section{Indicator species}

Indicator species are species that require certain growth requirements or those with narrow ecological amplitude ranges and can only live in certain environments (Widyatmoko and Irawati 2007). The results of the observation of indicator tree species diversity in the Bedugul Bali forest area highlighted 13 species. Spread in the Bukit Mangu forest area, there were 5 species namely Ficus sp, Platea latifolia, Polyosma integrifolia, Lindera sp. and Syzygium sp., There were 4 species on Bukit Tapak, namely Casuarina junghuhniana, Acronychia trifoliate, Astronia spectabilis and Homalanthus giganteus. There were also 4 species in the forest of Bukit Lesung, namely Lophopetalum javanicum, Syzygium racemosum, Dysoxylum nutans and Dendrocnide peltata Table 4. 
Table 4. Trees species indicator in Bedugul Forest Ecosystem. Asterisk refers to indicator species

\begin{tabular}{|c|c|c|c|}
\hline Elevation class & Mangu Hill Forest & Tapak Hill Forest & Lesung Hill Forest \\
\hline $\begin{array}{l}1.116-1.420 \mathrm{~m} \text { asl } \\
\text { (Lower) }\end{array}$ & $\begin{array}{l}\text { Polyosma integrifolia* } \\
\text { Syzygium sp.* } \\
\text { Ficus } \text { sp* }^{*}\end{array}$ & & $\begin{array}{l}\text { Lophopetalum javanicum* } \\
\text { Syzygium racemosum } \\
\text { Dysoxylum nutans } \\
\text { Dendrocnide peltata* } \\
\text { De }\end{array}$ \\
\hline $\begin{array}{l}\text { 1.421-1.697 } \mathrm{m} \text { asl } \\
\text { (Middle) }\end{array}$ & $\begin{array}{l}\text { Platea latifolia* } \\
\text { Syzygium sp.* }\end{array}$ & $\begin{array}{l}\text { Dacrycarpus imbricatus } \\
\text { Acronychia trifoliate* } \\
\text { Homalanthus giganteus* } \\
\text { Astronia spectabilis* }\end{array}$ & $\begin{array}{l}\text { Lophopetalum javanicum* } \\
\text { Syzygium racemosum* } \\
\text { Dacrycarpus imbricatus } \\
\text { Dysoxylum nutans } * \\
\text { Dendrocnide peltata* }\end{array}$ \\
\hline $\begin{array}{l}1.698-2.002 \mathrm{~m} \text { asl } \\
\text { (Upper) }\end{array}$ & $\begin{array}{l}\text { Platea latifolia* } \\
\text { Polyosma integrifolia* } \\
\text { Lindera } \text { sp. }^{*}\end{array}$ & $\begin{array}{l}\text { Acronychia trifoliate* } \\
\text { Dacrycarpus imbricatus } \\
\text { Astronia spectabilis* } \\
\text { Homalanthus giganteus* } \\
\text { Casuarina junghuhniana* }\end{array}$ & $\begin{array}{l}\text { Lophopetalum javanicum* } \\
\text { Syzygium racemosum* } \\
\text { Dacrycarpus imbricatus }\end{array}$ \\
\hline
\end{tabular}

Based on the zoning of indicator tree species in each location, the Bukit Mangu Bawah forest area (MB) contained Polyosma integrifolia, Syzygium sp. and Ficus sp., Mangu Tengah (MT) showed the presence of Platea latifolia and Syzygium sp. Mangu Atas (MA) contained Platea latifolia, Polyosma integrifolia and Lindera sp. Bukit Tapak Bawah forest area (TB) has no indicator species. In Middle Tapak (TT), there were Acronychia trifoliate, Homalanthus giganteus and Astronia spectabilis. There were Acronychia trifoliate, Astronia spectabilis, Homalanthus giganteus and Casuarina junghuhniana, in the Tapak Atas (TA). Whereas, the Bukit Lesung Bawah (LB) forest area contains Lophopetalum javanicum, Syzygium racemosum, Dysoxylum nutans and Dendrocnide peltata, Bukit Lesung Tengah (LT) contained Lophopetalum javanicum, Syzygium racemosum, Dysoxylum nutans and Dendrocnide peltata. Bukit Lesung Atas (LA) contains Lophopetalum javanicum and Syzygium racemosum.

Indicator species has been used in many ecological research, however mostly these are in a form of animal species or microorganism, moreover these indicators usually refers to a species in degraded or disturbed habitat (Bachand et al. 2014; Broyer 2009; Newton and Horner 2003). Plant species can also be used as indicators. Johnston et al. (2007) studied the relationship of plant species which were identified as indicators in the U.S Great Lakes coastal wetlands with their environmental preference in the habitat. According to Carrignan and Villard (2002), indicator species can be used for assessing ecosystem integrity. However, Carrignan and Villard (2002) conclude that it can be useful if: " (i) many species representing various taxa and life histories are included in the monitoring program, (ii) their selection is primarily based on a sound quantitative database from the focal region, and (iii) caution is applied when interpreting their population trends to distinguish actual signals from variations that may be unrelated to the deterioration of ecological integrity."
One of the few studies concerning the use of tree species as indicators of mountain forest ecosystem was of Mirmanto (2014). However, in his study the elevation range was mainly categorized only as lower and upper. Moreover, in our study, we applied higher elevations than of Mirmanto. Mirmanto found that the lower elevation zone (700-1000 m asl) comprised of species such as Pternandra coerulescens, Villebrunea rubescens Pometia pinnata, Glochidion rubrum and Horsfieldia glabra. This result is different from our findings in Bedugul Forests. This is due to, perhaps, difference in the altitudinal and other environmental factor (s). In the upper slope, Astronia spectabilis, Castanopsis javanica, Engelhardia spicata, Podocarpus imbricatus, P. neriifolius, Schima walichii and Polyosma ilicifolia were present. These results are almost similar with ours. Species such as Astronia spectabilis, Podocarpus imbricatus (Dacrycarpus imbricatus), Astronia spectabilis, Engelhardia spicata and also from genus Polyosma were also present in the upper elevation zone in Bedugul forests ecosystem. These species were known as species that typify the vegetation in the mountain zone (Mirmanto 2014). Therefore, in general we can draw a conclusion that the forest ecosystem in Bedugul is rather intact or less disturbed. However, in several parts of Bedugul such as on Pohen Hill, the forest was undergoing secondary succession due to huge forest fire in 1994 (Sutomo 2009). Additionally, the Phen Hill's forest also affected by the geothermal power plant station which caused edge effect to the forest and facilitate the establishment of pioneer (Homalanthus gigantheus, Macaranga sp.) and or invasive species (Lantana camara, Chromolaena odorata, Imperata cylindrica) (Fardila and Sutomo 2011).

\section{ACKNOWLEDGEMENTS}

The authors would like to thank the head of the UPT BKT Bali Eka Karya Botanic Gardens I Gusti Made 
Sudirga, I Ketut Sandi and his staff for all the facilities and assistance provided so that these sub-activity agendas in 2014 can be carried out. Thanks are also conveyed to the head of the Prov. Natural Resources Conservation Center. Bali for research permits in Taman Wisata Alam Beratan, Buyan and Tamblingan and Cagar Alam Batukahu.

\section{REFERENCES}

Bachand M, Pellerin S, Côté SD, et al. 2014. Species indicators of ecosystem recovery after reducing large herbivore density: comparing taxa and testing species combinations. Ecol Indicat 38: 12-19.

BIG [Badan Informasi Geospasial]. 2000. Peta Rupa Bumi Lembar 1707631 (Sukasada), 1707-632 (Gitgit), 1707-613 (Pupuan) dan 1707614 (Baturiti). [Indonesian]

Broyer J. 2009. Compared distribution within a disturbed fishpond ecosystem of breeding ducks and bird species indicators of habitat quality. J Ornithol 150 (4): 761-768.

Carignan V, Villard MA. 2002. Selecting indicator species to monitor ecological integrity: a review. Environ Monit Assess 78 (1): 45-61.

Cox GW. 1967. Laboratory Manual of General Ecology. WmC Brown. Iowa.

Crisana CW. 2014. Analisis Perbandingan Metode Klasifikas Autocorrelation Based Regio classification (ACRC) Dan Non-ACRC Untuk Data Spasial. [Hon. Thesis]. Fakultas Matematika dan Ilmu Pengetahuan Alam, Institut Pertanian Bogor, Bogor. [Indonesian]

Darma IDP, Lestari WS, Priyadi A. 2015. Habitat alami tumbuhan paku kidang (Dicksonia blumei (Kunze) Moore) di Kawasan Hutan Bukit Tapak Pulau Bali. Buletin Kebun Raya 18 (1): 49-57. [Indonesian]

Darnaedi, Siregar M, Soedjito H, Sukara E. 2005. Konsep cagar biosfer: alternatif pengelolaan kawasan tri-danau Beratan, Buyan dan Tamblingan, Provinsi Bali. In: Hehanusa PE, Abdulhadi R, Siregar M (eds). Prosiding Simposium "Analisis daya dukung dan daya tampung sumber air di Kawasan Tri-Danau Beratan, Buyan dan Tamblingan Provinsi Bali”. UPT BKT KR 'Eka Karya' Bali-LIPI, Tabanan. [Indonesian]

De Caceres M, Legendre P. 2009. Associations between species and groups of sites: Indices and statistical inference. Ecology 90 (12): 3566-3574

Fardilla D, Sutomo. 2011. Efek Tepi Koridor Jalan di Hutan Bukit Pohen Cagar Alam Batukahu Bali. Berkala Penelitian Hayati J Biol Res 17: 9-13. [Indonesian]
MFA [Ministry of Foreign Affairs]. 2016. Menlu RI: Pengelolaan Cagar Biosfer Sebagai Wujud Pembangunan Berkelanjutan di Indonesia. https:/www.kemlu.go.id/id/berita/Pages/Menlu-RI-PengelolaanCagar-Biosfer-Sebagai-Wujud-Pembangunan-Berkelanjutan-diIndonesia.aspx [Indonesian]

Hehanusa PE. 2005. Penataan ruang dan daya dukung sumber daya air di cekungan terkungkung Beratan-Buyan-Tamblingan Provinsi Bali. In: Hehanusa PE, Abdulhadi R, Siregar M (eds). Prosiding Simposium "Analisis daya dukung dan daya tampung sumber air di Kawasan TriDanau Beratan, Buyan dan Tamblingan Provinsi Bali”. UPT BKT KR 'Eka Karya' Bali-LIPI, Tabanan. [Indonesian]

Iryadi R, Priyadi A, Darma IDP. 2017. Penggunaan citra satelit untuk mengetahui persebaran Dacrycarpus imbricatus (Blume) de Laub. di Bukit Tapak, Cagar Alam Batukahu Bali. Jurnal Ilmu Kehutanan 11 (2): 130-141. [Indonesian]

Johnston CA, Bedford BL, Bourdaghs M, et al. 2007. Plant species indicators of physical environment in Great Lakes coastal wetlands. J Gt Lakes Res 33: 106-124.

Kent M. 2011. Vegetation Description and Data Analysis: A Practical Approach. John Wiley \& Sons, New York.

MAB-Indonesia. 2013. Peta Area Cagar Biosfer. http://www.mabindonesia.org/cagar.php. [Indonesian]

Mirmanto E. 2014. Fitososiologi Hutan Pegunungan di Lereng Tenggara Gunung Salak. Jurnal Biologi Indonesia 10 (1): 27-38. [Indonesian]

Mitchell K. 2015. Quantitative analysis by the point-centered quarter method. arXiv: 1010.3303, 2010.

Newton JA, Horner RA. 2003. Use of phytoplankton species indicators to track the origin of phytoplankton blooms in Willapa Bay, Washington. Estuaries 26 (4): 1071-1078.

$\mathrm{R}$ Core Team. 2013. R: A language and environment for statistical computing. R Foundation for Statistical Computing, Vienna, Austria.

Sumantera IW. 2004. The potency of Bukit Tapak forest as means for traditional ceremony, environmental conservation, and education. Biodiversitas 5 (2): 81-84

Sutomo. 2015. Groundcover Plant Community Composition in a 1 ha Permanent Plot on Pohen Mountain Batukaru Nature Reserve Bali. Metamorfosa Journal of Biological Sciences 2: 41-49. [Indonesian]

Sutomo. 2009. Vegetation Condition and Guidance for Forest Ecosystem Restoration on Post Fire Area of Pohen Hill Batukahu Nature Reserve Bali (A Literature Review). Jurnal Biologi Universitas Udayana 13: 45-50.

Widyatmoko D, Irawati. 2007. Kamus istilah Konservasi. Pusat Konservasi Tumbuhan Kebun Raya Bogor-LIPI, Bogor. [Indonesian]

Witono JR, Mogea JP, Somadikarta S. 2002. Pinanga in Java and Bali. Palms 46 (4): 193-201. 